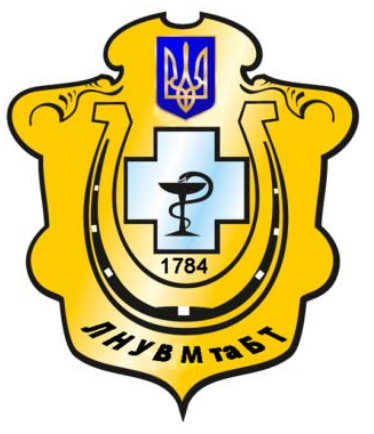

Науковий вісник Львівського національного університету ветеринарної медицини та біотехнологій імені С.3. Гжицького

Scientific Messenger of Lviv National University of Veterinary Medicine and Biotechnologies named after S.Z. Gzhytskyj

doi:10.15421/nvlvet6602

ISSN 2413-5550 print

ISSN 2518-1327 online

$\underline{\text { http://nvlvet.com.ua/ }}$

УДК 619:614.31.15:658.562.018/.4:637.56

\title{
Контроль якості риби за застосування вдосконаленого методу визначення вологоутримуючої здатності м'яса
}

\author{
Н.М. Богатко ${ }^{1}$, Н.В. Букалова ${ }^{1}$, Л.М. Богатко ${ }^{1}$, В.3. Салата ${ }^{2}$, Л.П. Артеменко ${ }^{1}$, Т.В. Полтавченко ${ }^{3}$ \\ nabogatko@yandex.ru, salatavolod@ukr.net \\ ${ }^{I}$ Білоиерківський національний аграрний університет, \\ пл. Соборна, 8/1, м. Біла Церква, 09111, Украӥна; \\ ${ }^{2}$ Львівський національний університет ветеринарной медицини та біотехнологій імені С.3. Гюсицького, \\ вул. Пекарська, 50, м. Львів, 79010, Украӥна; \\ ${ }^{3}$ Начіональний університет водного господарства та природокористування, \\ вул. Соборна, 11, м. Рівне, 33028, Украӥна
}

Розроблено вдосконалений метод визначення вологоутромуючої здатності м'яса риби шляхом виділення води із наважки м'яса риби методами пресування та висушування за температури 105 - $106{ }^{\circ} \mathrm{C}$ i визначення ї̈ по масовій частиі та вирахуванням у процентах за формулою, щуо забезпечить достовірність результатів при встановленні якості риби.

Розроблений вдосконалений метод визначення вологоутримуючої здатності м'яса риби має вірогідність у показниках 99,4\% та може застосовуватися для визначення якості риби за різного ступеня термічної обробки: свіжого, охолодженого, мороженого, дефростованого, варено-мороженого при визначенні його якості у виробничих лабораторіях на потужностях з переробки риби, підприємствах по реалізації та зберіганні риби (магазинах, супермаркетах, оптових базах тощь), у державних лабораторіях ветеринарної медицини та у лабораторіях ветеринарно-санітарної експертизи на агропромислових ринках в комплексі з іншими методами визначення якості риби.

Встановлено, що вірогідність показників вологоутримуючої здатності м'яса риби у порівнянні до показників визначення масової частки води у м'ясі риби становила 97,8 - 98,9\%, та до показників визначення масової частки жиру у м'ясі риби $97,9-99,0 \%$

Встановлено дослідженнями, щңо вологоутримуюча здатність м'яса риби залежить від термічної обробки риби, виду риби, масової частки води та жиру. Так найвища вологоутримуюча здатність відмічалася у м'ясі свіжої риби коропа 72,6 $\pm 1,7 \%$, найнижча - у дефростованої (розмороженої) риби окуня - 51,3 $\pm 1,6 \%$. На даний метод розроблений Патент України на корисну модель № 109387.

Ключові слова: вдосконалений метод, безпечність, якість, м'ясо риби, вологоутримуюча здатність, нагляд (контроль), термічна обробка риби.

\section{Контроль качества рыбы при использовании усовершенствованого метода определения влагоудерживающей способности мяса}

\author{
Н.М. Богатко ${ }^{1}$, Н.В. Букалова ${ }^{1}$, Л.М. Богатко ${ }^{1}$, В.З. Салата ${ }^{2}$, Л.П. Артеменко ${ }^{1}$, Т.В. Полтавченко ${ }^{3}$ \\ nabogatko@yandex.ru, salatavolod@ukr.net \\ ${ }^{1}$ Белочерковский национальный аграрный университет, \\ пл. Соборная, 8/1, г. Белая Церковь, 09111, Украина; \\ ${ }^{2}$ Львовский нацииональный университет ветеринарной медицины и биотехнологий имени С.3. Гжицкого, \\ ул. Пекарская, 50, г. Львов, 79010, Украина; \\ ${ }^{3}$ Нацииональный университет водного хозяйства и природоиспользования, \\ ул. Соборная, 11, г. Ровно, 33028, Украина
}

\section{Citation:}

Bogatko, N.M., Bukalova, N.V., Bogatko, L.M., Salata, V.Z., Artemenko, L.P., Poltavchenco, T.V. (2016). Control of quality of fish by use of an improved method for the determination of water-holding capacity of meat. Scientific Messenger LNUVMBT named after S.Z. Gzhytskyj, 18, 2(66), 8-12. 
Разработан усовершенствованный метод определения влагоудерживаюшей способности мяса рыбы путем отделения воды из навески мяса рыбы методами пресования и высушивания при температуре 105 - $106{ }^{\circ} \mathrm{C} i$ определения ее по удельному весу и вычеслениям в прочентах по формуле, что обеспечит достоверность результатов при определении качества рыббы.

Разработанный усовершенствованный метод определения влагоудерживаюшей способности мяса рыбы составляет достоверность в показателях 99,4\% и может применяться для определения качества рыбы разной степени термической обработке: свежей, охлажденной, мороженой, дефростованой, варено-мороженой при определении ее качества у производственных лабораториях на предприятиях с переработки рыбы, предприятиях по реализации и хранению рыбы (магазинах, супермаркетах, оптовых базах), в государственных лабораториях ветеринарной медицинь и у лабораториях ветеринарно-санитарной экспертизы на агропродовольственных рынках в комплексе с другими методами определения качества рыбы.

Установлено, что достоверность показателей влагоудержсвающей способности мяса рыбы в сравнении к показателям определения удельного веса воды в мясе рыбы составляла 97,8 - 98,9\%, и к показателям определенияудельного веса жира в мясе рыбыл-97,9-99,0\%.

Установлено исследованиями, что влагоудерживающая способность мяса рыбы зависит от термической обработки рыбы, вида рыбы, удельного веса воды и жира. Так наибольшая влагоудерживаюшая способность отмечалась в мясе свежей рыбы коропа - 72,6 \pm 1,7\%, наименьшая - в дефростованой (размороженой) рыбы окуня - 51,3 $\pm 1,6 \%$. На данный метод разработан Патент Украины на полезную модель № 109387.

Ключевые слова: усовершенствованный метод, безопасность, качество, мясо рыбы, влагоудерживающая способность, надзор (контроль), термическая обработка рыбы.

\title{
Control of quality of fish by use of an improved method for the determination of water-holding capacity of meat
}

\author{
N.M. Bogatko ${ }^{1}$, N.V. Bukalova ${ }^{1}$, L.M. Bogatko ${ }^{1}$, V.Z. Salata $^{2}$, L.P. Artemenko ${ }^{1}$, T.V. Poltavchenco ${ }^{3}$ \\ nabogatko@yandex.ru, salatavolod@ukr.net \\ Bila Tserkva National Agrarian University, \\ Soborna sq., 8/1, Bila Tserkva, 09111, Ukraine; \\ Lviv national university of veterinary medicine and biotechnologies named after S. Gzhytskyj, \\ Pekarska Str., 50, Lviv, 79010, Ukraine; \\ National University of Water and Environmental Engineering, Rivne, Ukraine \\ Soborna Str., 11, Rivne, 33028, Ukraine
}

Developed an improved method for the determination of water-holding capacity of fish meat by extracting water from a sample of fish meat by the methods of pressing and drying at a temperature of $105-106{ }^{\circ} \mathrm{C}$ and determine its mass fraction and less in percent by the formula, which will ensure the reliability of results in determining the quality of the fish.

Developed an improved method for determining water-holding capacity of fish meat has a probability in the performance $99.4 \%$ and can be used to determine the quality of fish at different degrees of heat treatment: fresh, chilled, ice cream, defrosting, cooked ice cream in the determination of its quality in the production laboratories at the facilities of fish processing enterprises on the implementation and storage of fish (stores, supermarkets, wholesale bases, etc.), in the state laboratories of veterinary medicine and in laboratories of veterinary-sanitary examination of agricultural markets in combination with other methods of determining the quality of the fish.

It is established that the reliability of the indicators of water-holding capacity of fish meat in comparison of the determination of the mass fraction of water in fish meat was $97.8-98.9 \%$ of and before the performance determination of the mass fraction of fat in the fish flesh $-97.9-99.0 \%$.

Established by research that of water-holding capacity of fish meat depends on the heat treatment of fish, fish species, the mass fraction of water and fat. So, of water-holding capacity he highest ability was observed in meat of fresh fish carp of $72.6 \pm 1.7 \%$, the lowest in damastown (thawed) fish perch 51,3 1,6\%. For this development Patents of Ukraine is got on an useful model № 109387.

Key words: advanced method, safety, quality, meat, fish, water-holding capacity of fish meat, supervision (control), heat treatment of fish.

\section{Вступ}

Одним із завдань Державної служби України з питань безпечності харчових продуктів та захисту споживачів є реалізація державної політики у галузі ветеринарної медицини, сферах безпечності та окремих показників якості харчових продуктів, державного нагляду (контролю) за дотриманням санітарного законодавства, ринкового нагляду в межах сфери своєї відповідальності.

Здійснюючи державний нагляд (контроль) за безпечністю та якістю харчових продуктів тваринного походження фахівці ветеринарної медицини повинні виконувати вимоги нової Європейської регламентації щодо харчових продуктів, Комісії Кодексу Аліментаріус, ФАО/ВООЗ, основних положень торгових Угод SPS i TBT, та організовувати свою роботу на основі оцінки ризиків із санітарної безпеки харчових продуктів (Bogatko et al., 2011).

Враховуючи значення м'яса забійних тварин та птиці у харчуванні людини, в нашій державі діє Закон України «Про основні принципи та вимоги до безпечності та якості харчових продуктів», у якому регламентується державне регулювання у сфері безпечності харчових продуктів 3 метою захисту життя, здоров'я та інтересів споживачів шляхом установлен- 
ня санітарних заходів; установлення вимог до окремих показників якості харчових продуктів; державної реєстрації об'єктів санітарних заходів; здійснення державного контролю тощо.

Для забезпечення безпечності м'ясної сировини для споживачів необхідно розробляти нові експресні методи контролю гігієни виробництва, зберігання та обігу м'яса, м'ясопродуктів. Особливо актуальними є напрями досліджень щодо розробки експресних методів, які дають змогу об'єктивно оцінити безпечність та якість м'яса забійних тварин та птиці за зберігання та реалізації або використання для виробництва м'ясопродуктів. У світовій науці і практиці застосовуються найчутливіші методи визначення якості та безпечності м'ясної сировини. В Україні також за останні роки вченими розроблені експресні методи визначення якості та безпечності продукції тваринництва (Page et al., 2011; Reichert, 2013; Bogatko et al., 2013; Bogatko et al., 2014).

Метою і завданням дослідження було розробити вдосконалений метод визначення вологоутримуючої здатності м'яса риби за різного ступеня термічної обробки та провести експертизу риби за деякими показниками.

\section{Матеріал і методи дослідження}

Для дослідження використовували 47 проб м'яса риби різного ступеня термічної обробки: 12 проб риба свіжа; 10 проб - риба охолоджена; 11 проб риба морожена; 8 проб - риба дефростована (розморожена); 6 проб - риба варено-морожена, що реалізувалися у супермаркетах м. Києва, м. Львова.

\section{Результати та їх обговорення}

Аналогом розробки вдосконаленого методу $\epsilon$ метод визначення масової частки води у м'ясі забійних тварин (яловичини, свинини, баранини тощо) шляхом висушування за температури $103{ }^{\circ} \mathrm{C}$, який базується на виділенні води із продукту за теплової обробки і визначенні зміни маси при його зважуванні. Недоліком даного методу $є$ те, що він довготривалий: необхідно висушувати продукти із м'яса забійних тварин упродовж 2 годин за температури $103{ }^{\circ} \mathrm{C}$, а також складність приготування кварцового піску ретельним промиванням, висушуванням, прокалюванням і просіюванням. Крім того, метод дає похибку у визначенні $30-35 \%$.

Прототипом вдосконаленого методу є метод визначення масової частки води у м'ясі риби шляхом висушування за температури $130{ }^{\circ} \mathrm{C}$, у якому використовують сушильну шафу для висушування наважки у кількості 1,5 - 2,0 г рибних продуктів. Недоліком даного методу є те, що він використовується для риби соленої, в'яленої, сушеної, холодного та гарячого копчення. Крім того, метод дає похибку у визначенні $20-25 \%$.
В основу розробки вдосконаленого методу було поставлено завдання -визначити вологоутримуючу здатність м'яса риби різного ступеня термічної обробки шляхом виділення води із наважки м'яса риби методами пресування та висушування за температури $105-106{ }^{\circ} \mathrm{C}$ і визначення іiі по масовій частці та вирахуванням у процентах за формулою, що забезпечить достовірність результатів при встановленні якості риби.

Для розробки методу використовували наважку м'яса риби різного ступеня термічної обробки у кількості 100,0 - 150,0 г, подрібнювали на електром'ясорубці, ретельно перемішували, не допускаючи втрати м'ясного соку, та поміщали у бюксу із притертою кришкою. Подрібнений фарш у кількості $0,3-$ 0,4 г поміщали на поліетиленовий кружок, який переносили на кружок фільтрувального паперу, який розміщали на скляній пластині так, щоб наважка фаршу лежала на фільтрувальному папері. Зверху поліетиленовий кружок накривали скляною пластиною, на яку ставили груз масою 1,0 кг і витримували пресування упродовж 9 - 10 хв. Після пресування наважку м'яса риби вивільнювали від фільтрувального паперу і поліетиленового кружка, поміщали у попередньо тарований бюкс, зважували і висушували у сушильній шафі за температури $105-106^{\circ} \mathrm{C}$ упродовж $4-5$ хв. У подальшому вологоутримуючу здатність м'яса риби $(\mathrm{X)}$ розраховували у процентах (\%) за формулою:

$$
\mathrm{X}=\frac{\mathrm{m}_{2} \mathrm{x}\left(\mathrm{m}_{1}-\mathrm{m}_{3}\right)}{\mathrm{m}_{1}} \text {, де }
$$

$\mathrm{m}_{1}$ - маса досліджуваної наважки до пресування, г; $\%$;

$\mathrm{m}_{2}$ - масова частка води у відпресованій наважці,

$\mathrm{m}_{3}$ - маса води, відпресованої із наважки, г; $\mathrm{m}_{3}=$ різниця між масою дослідної наважки риби до пресування та масою досліджуваної наважки риби після пресування.

Результати визначення вологоутримуючої здатності м'яса риби наведено у таблиці 1 .

Дані таблиці 1 свідчать, що більш вірогідні дані у порівнянні до показників визначення масової частки води у м'ясі риби - у 97,8 - 98,9\% та до показників визначення масової частки жиру у м'ясі риби - у 97,9 - 99,0\% були отримані при застосуванні розробленого методу. Також вірогідність показників по визначенню вологоутримуючої здатності м'яса риби різного ступеня термічної обробки складала - 99,4\% (Bogatko et al., 2016).

Використовуючи розроблений метод, ми визначили вологоутримуючу здатність м'яса риби різного ступеня термічної обробки на 47 пробах: 12 проб риба свіжа; 10 проб - риба охолоджена; 11 проб риба морожена; 8 проб - риба дефростована (розморожена); 6 проб - риба варено-морожена. Попередньо проби м'яса риби були досліджені за деякими хімічними показниками (Bogatko et al., 2011). 
Таблиця 1

Показники розробленого методу визначення вологоутримуючої здатності м'яса риби різного ступеня термічної обробки

\begin{tabular}{|c|c|c|}
\hline № & Складові методу: & Показники \\
\hline 1. & $\begin{array}{l}\text { Маса наважки м’яса риби, г } \\
\text { Кількість подрібненого фаршу із м’яса риби, г; }\end{array}$ & $\begin{aligned} 100,0 & -150,0 \\
0,3 & -0,4\end{aligned}$ \\
\hline 2. & $\begin{array}{l}\text { Маса грузу, кг } \\
\text { Час пресування, хв. }\end{array}$ & $\begin{array}{c}1,0 \\
9-10\end{array}$ \\
\hline 3. & $\begin{array}{l}\text { Час висушування, хв } \\
\text { Температура висушування, }{ }^{\circ} \mathrm{C}\end{array}$ & $\begin{array}{c}4-5 \\
105-106\end{array}$ \\
\hline 4. & Швидкість визначення досліду, хв & $20-22$ \\
\hline 5. & Вірогідність показників вологоутримуючої здатності м’яса риби ,\% & 99,4 \\
\hline 6. & $\begin{array}{l}\text { \% співвідношення результатів досліджень до показників масової частки води } \\
\text { у м’ясі риби }\end{array}$ & $97,8-98,9$ \\
\hline 7. & $\begin{array}{l}\text { \% співвідношення результатів досліджень до показників масової частки жиру у } \\
\text { м’ясі риби }\end{array}$ & $97,9-99,0$ \\
\hline
\end{tabular}

Результати досліджень за деякими хімічними показниками та вологоутримуючою здатністю м'яса риби різного ступеня термічної обробки представлено у таблиці 2.

Проведеними дослідженнями визначено, що вологоутримуюча здатність м'яса риби залежить від термічної обробки риби, виду риби, масової частки води та жиру. Так найвища вологоутримуюча здатність відмічалася у м'ясі свіжої риби коропа $72,6 \pm 1,7 \%$, найнижча - у дефростованої (розмороженої) риби окуня $-51,3 \pm 1,6 \%$. Ці дані були стабільними та достовірними, отже ці показники можна використовувати при оцінці якості м'яса риби різного ступеня термічної обробки.
Крім того, слід зазначити, що розроблений вдосконалений метод $є$ простим у виконанні, а його результати дають конкретні кількісні показники вологоутримуючої здатності м'яса риби для встановлення ii якості за різного ступеня термічної обробки. Тому даний метод пропонується нами, як кількісний спосіб для визначення вологоутримуючої здатності м'яса риби різного ступеня термічної обробки поряд з іншими методами визначення якості риби (органолептика; масові частки води, жиру, сухої речовини; величина pН тощо) (Bogatko et al., 2011). Метод має перевагу перед існуючими методами визначення якості риби за різного ступеня термічної обробки в тому, що результати мають конкретне, достовірне кількісне значення.

Таблиия 2

Хімічні показники та вологоутримуюча здатність м'яса риби різного ступеня термічної обробки

\begin{tabular}{|c|c|c|c|c|c|c|}
\hline $\begin{array}{l}\text { № } \\
\text { ח/ח }\end{array}$ & $\begin{array}{c}\text { Вид термічної обробки } \\
\text { різних видів риби }\end{array}$ & $\begin{array}{l}\text { К-ть } \\
\text { проб }\end{array}$ & $\begin{array}{c}\text { Масова частка } \\
\text { води, \% }\end{array}$ & $\begin{array}{c}\text { Масова частка } \\
\text { сухої речови- } \\
\text { ни, \% }\end{array}$ & $\begin{array}{c}\text { Масова частка } \\
\text { жиру, \% }\end{array}$ & $\begin{array}{c}\text { Вологоутримуюча здат- } \\
\text { ність м'яса риби за вдос- } \\
\text { коналеним методом, \% }\end{array}$ \\
\hline 1 & $\begin{array}{l}\begin{array}{l}\text { М'ясо } \\
\text { (короп) }\end{array} \\
\text { свіжої }\end{array}$ & 12 & $75,5 \pm 1,5$ & $19,8 \pm 0,9$ & $4,5 \pm 0,2$ & $72,6 \pm 1,7$ \\
\hline 2 & $\begin{array}{l}\text { М'ясо охолодженої } \\
\text { риби (товстолобик) }\end{array}$ & 10 & $56,8 \pm 1,2$ & $18,6 \pm 0,8$ & $23,2 \pm 0,8$ & $68,9 \pm 1,4$ \\
\hline 3 & $\begin{array}{l}\text { М'ясо мороженої риби } \\
\text { (карась) }\end{array}$ & 11 & $79,5 \pm 1,7$ & $19,1 \pm 1,2$ & $1,4 \pm 0,1$ & $62,7 \pm 1,9$ \\
\hline 4 & $\begin{array}{l}\text { М'ясо дефростованої } \\
\text { риби (окунь) }\end{array}$ & 8 & $81,3 \pm 1,8$ & $18,0 \pm 1,1$ & $0,7 \pm 0,01$ & $51,3 \pm 1,6$ \\
\hline 5 & $\begin{array}{ll}\text { M'ясо } & \text { варено- } \\
\text { мороженої риби (сом) }\end{array}$ & 6 & $71,3 \pm 1,5$ & $19,5 \pm 1,2$ & $9,2 \pm 0,2$ & $56,8 \pm 1,4$ \\
\hline
\end{tabular}

\section{Висновки}

1. Даний розроблений метод може бути використаний для визначення вологоутримуючої здатності м'яса риби за різного ступеня термічної обробки: свіжого, охолодженого, мороженого, дефростованого, варено-мороженого при визначенні його якості у виробничих лабораторіях на потужностях 3 переробки риби, підприємствах по реалізації та зберіганні риби (магазинах, супермаркетах, оптових базах тощо), у державних лабораторіях ветеринарної медицини та у лабораторіях ветеринарно-санітарної експертизи на агропромислових ринках в комплексі 3 іншими методами визначення якості м'яса риби. Вірогідність методу складає 99,4\%.

2. Встановлено, що найвища вологоутримуюча здатність відмічалася у м'ясі свіжої риби коропа $72,6 \pm 1,7 \%$, найнижча - у дефростованої (розмороженої) риби окуня - 51,3 $\pm 1,6 \%$.

Перспективи подальших досліджень полягають у проведенні апробації у державних лабораторіях ветеринарної медицини розробленого методу вдосконалення визначення вологоутримуючої здатності м'яса риби. Запропонований метод після апробації буде впроваджено на підприємствах рибної промисловості для визначення якості риби. У перспективі автори планують розробити нормативний документ на метод вдосконалення визначення вологоутримуючої здатності м'яса риби 


\section{Бібліографічні посилання}

Bogatko, N.M., Vlasenko, V.V., Golub, A.Yu. (2011). State veterinary-sanitary supervision and control capacities of fish processing and fish products in accordance with international requirements: guidelines for students PNXM practical doctors of veterinary medicine, students and undergraduates FVM. White Church.

Reichert, J.E. (2013). Possible methods of automatic on leni determination of quality parameters when classifying and selecting carcasses and meat cuts. fleischwirtschaft is International. Bd. 6, 8-15.

Page, J.K., Wulf, D.M., Schwotzer, T.R. (2011). A survey of beef color and pH. J. Animal Science. 6, 21-27.

Bogatko, N.M., Bukalova, N.V., Kabluchko, M.V. (2014). Method improvement of determination of sodium chloride in riboprodukt. the Patent of Ukraine for useful model 86940, IPC G01N 33/12 (2006.01). no u 2013 10257; Appl. 20.08.2013; publ. 10.01.2014, bull. No. 1. -4 p.

Bogatko, N.M., Bukalova, N.V., Kabluchko, M.V. (2013). A method of improving photometric method determination of histamine in riboprodukt. the Patent of Ukraine for useful model 86941, IPC G01N 33/12 (2006.01). no u 2013 10258; Appl. 20.08.2013; publ. 10.01.2014, bull. No. 1. -6 p.

Bogatko, N.M., Bukalova, N.V., Poltavchenko, T.V., Salata, V.Z. (2016). The method of determining water-holding capacity of fish meat at different degrees of heat treatment. the Patent of Ukraine for useful model 109387, IPC G01N 33/12 (2006.01). - No. u 2016 01566; Appl. 22.02.2016; publ. 25.08.2016, bull. No. 16. -4 p.

Стаття надійшла до редакиії 29.09.2016 